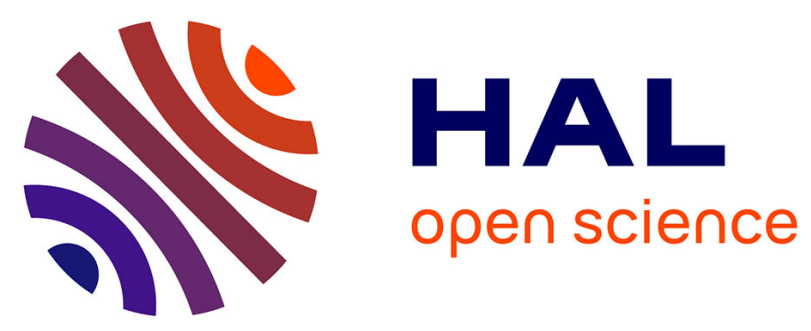

\title{
Organic composition of epilithic biofilms from agricultural and urban watershed in south Brazil
}

Gracieli Fernandes, Marilia Camotti Bastos, Leslie Mondamert, Jérôme Labanowski, Robert Alan Burrow, Danilo dos Santos Rheinheimer

\section{- To cite this version:}

Gracieli Fernandes, Marilia Camotti Bastos, Leslie Mondamert, Jérôme Labanowski, Robert Alan Burrow, et al.. Organic composition of epilithic biofilms from agricultural and urban watershed in south Brazil. Environmental Science and Pollution Research, 2021, 28 (22), pp.28808-28824. 10.1007/s11356-020-11389-5 . hal-03407936

\section{HAL Id: hal-03407936 \\ https://hal.science/hal-03407936}

Submitted on 28 Oct 2021

HAL is a multi-disciplinary open access archive for the deposit and dissemination of scientific research documents, whether they are published or not. The documents may come from teaching and research institutions in France or abroad, or from public or private research centers.
L'archive ouverte pluridisciplinaire HAL, est destinée au dépôt et à la diffusion de documents scientifiques de niveau recherche, publiés ou non, émanant des établissements d'enseignement et de recherche français ou étrangers, des laboratoires publics ou privés. 
1 Organic composition of epilithic biofilms from agricultural and urban 2 watershed in south Brazil

3

4 Gracieli Fernandes ${ }^{1 * *}$, Marilia Camotti Bastos $^{2}$, Leslie Mondamert ${ }^{3}$, Jérôme 5 Labanowski $^{4}$, Robert Alan Burrow ${ }^{5}$ and Danilo Rheinheimer dos Santos ${ }^{6}$

${ }^{1}$ Universidade Federal de Santa Maria, UFSM; gracieligfer@gmail.com

${ }^{2}$ Universidade Federal de Santa Maria, UFSM; marilia.camotti-bastos@unilim.fr

${ }^{3}$ Université de Poitiers, Univ. Poitiers; leslie.mondamert@univ-poitiers.fr

${ }^{4}$ Université de Poitiers, Univ. Poitiers; jerome.labanowski@ univ-poitiers.fr

${ }^{5}$ Universidade Federal de Santa Maria, UFSM; rburrow@ufsm.br

${ }^{6}$ Universidade Federal de Santa Maria, UFSM; danilo.rheinheimer@pq.cnpq.br

* Correspondence: gracieligfer@gmail.com; Universidade Federal de Santa Maria, Avenida Roraima n ${ }^{\circ}$ 1000, Cidade Universitária, Bairro Camobi. Centro de Ciências Rurais, Prédio 42, Departamento de Solos, Santa Maria - Rio Grande do Sul, Brazil. CEP: 97105-900. Tel.: (55) 3220-8136.

17 Corresponding author

\section{GRACIELI FERNANDES}

Full postal address: Universidade Federal de Santa Maria, Avenida Roraima n ${ }^{\circ}$ 1000, Cidade

Universitária, Bairro Camobi. Centro de Ciências Rurais, Prédio 42, Departamento de Solos,

21 Santa Maria - Rio Grande do Sul, Brazil. CEP: 97105-900.

Telephone number: (55) 3220-8136; (55) 99918-1832

E-mail address: gracieligfer@gmail.com

ORCiD: https://orcid.org/0000-0002-7264-1785

\section{Acknowledgments}

The authors thank Clarissa Piccinin Frizzo for assistance with spectral measurements and to Núcleo de Análises e Pesquisas Orgânicas of the Chemistry Department of the Universidade Federal de Santa Maria for technical support. 
Organic composition of epilithic biofilms from agricultural and urban watershed in south Brazil

Abstract

Active functional groups in biofilms determine the adsorption and desorption of contaminants and nutrients. Epilithic biofilms were characterized in order to understand the association between the chemistry alteration patterns and the surrounding anthropic activities of the Guaporé River watershed. The instrumental analyses included pyrolysis coupled to gas chromatography and mass spectroscopy, spectroscopy in the IR region with attenuated total reflectance and two-dimensional nuclear magnetic resonance. Spectrometric techniques demonstrated that epilithic biofilms are mainly composed of polysaccharides, nitrogencontaining compounds, lipids, and aromatic and phenolic structures, which have functional groups characteristic of alcohols, esters, ethers and amides. The polysaccharide levels reflect well the environmental pressures. The chemical composition of epilithic biofilms can be an effective tool for environmental assessment in watercourses, since the different anthropic actions developed in watersheds, mainly agriculture and urban areas, can modify the organic fraction of biofilms.

Keywords: environment; anthropic activities; epilithic biofilms; chemical composition; functional groups; spectrometric techniques.

\section{Introduction}

Intensification of anthropic activities (urban or rural) continually exposes water resources worldwide to different sources of pollution. Many contaminants (physical, biological or chemical) reach water bodies through natural events, such as rainfall and surface runoff, contributing to the degradation of water quality (Bhuyan et al. 2017). Microorganisms present in rivers or lakes are among the first aquatic organisms to come into contact with such contaminants (Sabater et al. 2007) and hence may present initial signs of modification at the onset of environmental changes, such as changes in the structure of the population or biogeochemical cycles (Sabater et al. 2007; Schneider and Lindstrom 2011). Recently, attention has been focused on epilithic biofilms as bioaccumulators of organic compounds for water quality studies (Aubertheau et al. 2017; Chonova et al. 2018; Fernandes et al. 2019; Rheinheimer et al. 2020). These biofilms are communities of colonizing organisms formed on submerged rocks (Aubertheau et al. 2017; Flemming et al. 2007), composed primarily of microbial cells (bacteria, fungi, protozoa, and algae), extracellular polymeric substances (EPS) produced by bacteria and algae, organic and inorganic materials, and detritus (Flemming et al. 
The biofilm structure remains attached to the rock through the EPS matrix, which includes polysaccharides, proteins, nucleic acids, phospholipids, and humic substances (Flemming and Wingender 2010). EPS can represent 50-90\% of the total organic carbon (TOC) present in biofilms (Matin et al. 2011). This matrix is responsible for imparting adhesive properties, surface fixation, and mechanical stability, allowing the organisms present in the biofilm to develop in association (Wuertz et al. 2004). The heterogeneity of biofilms and the metabolic processes of the various constituent microorganisms result in physicochemical microzones with substrate gradients and metabolic products (Stewart and Franklin 2008). In this sense, several biofilm components (living organisms, EPS, organic compounds, and minerals) can interact with chemical compounds contained in water (Julien et al. 2014), especially inorganic and organic contaminants.

The composition of the epilithic biofilm, especially the presence of distinct functional groups present in EPS, can play an important role in the retention of, inorganic contaminants (e.g.: heavy metals), organic contaminants (e.g.: pesticide residues and drugs) and nutrients (Flemming et al. 2007). Thus, the characterization of the in situ epilithic biofilms composition, especially if associated with the surrounding anthropic activities, could be an important tool in determining its adsorption potential. The determination of the organic molecular structure of EPS active functional groups can be carried out with standard techniques used in organic geochemistry such as: (i) gas chromatography coupled to mass spectroscopy (CG/MS), (ii) infrared spectroscopy (IR), (iii) nuclear magnetic resonance (NMR) spectroscopy, (iv) liquid chromatography-organic carbon detection-organic nitrogen detection (LC-OCD-OND) (Stewart et al. 2012) e (v) confocal laser scanning microscopy (CLSM) (Schlafer and Meyer 2017).

Pyrolysis coupled to gas chromatography and mass spectroscopy (PY-CG/MS) can establish the mean distributions of biopolymers present in biofilms (Julien et al. 2014). Proteins, polysaccharides, and, to a lesser extent, nucleic acids are the major components present in biofilms, indicating that their formation is associated with EPS production (Zhang et al. 2015). Exposure of biofilms to different nutritional conditions - that is, to environments 100 with different anthropic pressures and soil uses - produces different macromolecular 101 compositions (Lin et al. 2014). With IR spectroscopy, the variability of the composition and 102 quantity of each component under the different conditions studied can be determined (Jiao et 103 al. 2010). The application of the Fourier Transform Infrared (FTIR) spectroscopic technique 104 to biofilms allows the detection of polysaccharides and nucleic acids (carbohydrates, DNA 
105 and RNA in the region of 1300 to $900 \mathrm{~cm}^{-1}$ ), as well as of proteins (1700 to $1500 \mathrm{~cm}^{-1}$ ) and

106 of lipids (2930 to $2860 \mathrm{~cm}^{-1}$ ) (Jiao et al. 2010). Two dimensional ${ }^{1} \mathrm{H}^{13}{ }^{13} \mathrm{C} \mathrm{NR}$ provides

107 details of the types and relative abundances of functional groups associated with the presence

108 of different biopolymers.

109 The study of the organic composition of epilithic biofilms can provide information

110 about the effects due to changes in anthropogenic pressure which took place before sampling,

111 i.e., epilithic biofilms are a more reliable matrix than active water sampling. Studies on the

112 composition and presence of functional groups of epilithic biofilms thus can contribute to

113 further knowledge about their interactions and ecological relationships with aquatic ecosys-

114 tems and the organisms that inhabit them. This knowledge should allow development of better

115 reliable biological indicators, based on the understanding of their interactions with the envi-

116 ronment and of the factors that influence the variability of a biofilm's ability to capture organ-

117 ic compounds (Bonnineau et al. 2020). The study of biofilms is of particular importance for

118 the Guaporé river watershed (Guaporé RW) where 90\% of suspended sediments (part of

119 which can be retained in the epilithic biofilms) originate from crop areas (Tiecher et al. 2017);

120 the rate of water runoff is high (Didoné et al. 2015); and several small urban agglomerations

121 without treated domestic residues (Bastos et al. 2018) are located.

122 Research on the chemical composition of biofilms mainly involves controlled

123 experimental systems (Lawrence et al. 2012; Fish et al. 2015). Some recent studies show

124 significant in situ results with regards to the composition of EPS (Sambalova et al. 2018;

125 Blanco et al. 2019). Studies which report the characterization of biofilms are scarce. Those

126 that do rarely use epilithic biofilms in their natural environment and/or do not extend the

127 research of their chemical constitution. Studies with emphasis on the characterization of

128 natural epilithic biofilms sampled in rural watersheds in Brazil have never been published.

129 The use of the chemical composition of epilithic biofilms is hypothesized to be as effective as

130 other methods for environmental assessment in water courses. The objective of the present

131 work is the characterization of epilithic biofilms to understand the alteration patterns 132 associated with surrounding anthropic activities.

133 


\section{Materials and Methods}

\section{Study area}

The Guapore RW, located in the state of Rio Grande do Sul, southern tip of Brazil (Figure 1), has a Cfa climate according to the Köppen climatic classification (Kottek and Rubel 2010). Its average annual rainfall ranges between 1,400 and $1,700 \mathrm{~mm}$ and its average annual temperature is $17.9{ }^{\circ} \mathrm{C}$. The watershed drains an area of $2490 \mathrm{~km}^{2}$ and is $153 \mathrm{~km}$ long, with topography predominately by little hilly relief (57\%) and hilly relief (25\%) in northern part (Table 1) (Castro Lima et al. 2020). Agriculture and livestock are the main economic activities, while urban areas occupy only $0.6 \%$ of the area (Tiecher et al. 2017).

Two sub-watersheds present in the northern part of the watershed, the Capingui River sub-watershed and the Marau River sub-watershed, were selected for sampling biofilms due to the varied sources of contamination (forest, agriculture, animal breeding, dam, urban - near the river and riverbanks). The Capingui River sub-watershed has an area of $269 \mathrm{~km}^{2}$, which contains crop lands mostly used for soybeans (Glycine max (L.) Merrill) and corn (Zea mays, L.) production in no-tillage systems, a preserved national forest and a dam. The Marau River sub-watershed, which has an area of $257 \mathrm{~km}^{2}$, had urban and rural activities. It is characterized by the predominance of family agriculture and livestock production, based on poultry, swine, and milk production. The soybean, corn and cereal production coexist with the livestock production. The sub-watershed has a contribution of wastewater from urban areas of the city of Marau (over 40 thousand inhabitants), in which there are agribusinesses, especially large slaughterhouses for swine and poultry for export, and leather processing and mechanical metal industry (Rheinheimer et al. 2020; Castro Lima et al. 2020).

The confluence of these two rivers (Capingui and Marau) gives rise to the Guaporé

158 River - an agronomically important river in the region, with a catchment area of $542 \mathrm{~km}^{2}-$

159 begins. This river is responsible for supplying the hydric needs of local agricultural activities 160 (soybean, corn, cereals, tobacco, vegetables and fruit), crops animal production (swine, 161 poultry and cattle), and, finally, for human consumption (Tiecher et al. 2017). The soil use is 162 composed of $66.8 \%$ crops and pastures; $22.4 \%$ forests; $5.2 \%$ exposed soil; $4.8 \%$ urban areas; $1630.8 \%$ water bodies.

\section{Sampling sites description}

The descriptions of the nine sampled sites are present below and in Table 1. 
The Capingui River sub-watershed sampled sites: 1300 hectares. The site represents the headwaters of sub-watershed and is considered as a control sample due to low anthropogenic action;

$C 2$ - the Capingui Dam site is located $600 \mathrm{~m}$ downstream from the Capingui River Dam spillway. The riparian forest is limited to a strip between 15 and $60 \mathrm{~m}$ wide and is bordered by grains production under no-tillage system. Currently, the dam is used for recreation and has an increasing human activity specially in summer, resulting in the release of wastewater directly into the dam reservoir;

C3 - the Agriculture site located $17 \mathrm{~km}$ from the Capingui dam and represents the contribution of a vast area of agricultural production. Crops occupy $69 \%$ of the area and are managed in no-tillage system with soybean and corn in spring/summer and oats/wheat in autumn/winter; and

C4 - the Capingui sub-watershed Outlet site which the crops occupy $71 \%$ of the neighboring area. The farming system is similar to that of the Agriculture site and, during the sampling, there was a large concentration of residues from the rearing of confined animals (mainly poultry and dairy cow).

The Marau River sub-watershed sampled sites:

$M 1$ and M2 (Integrate Agriculture/Animal) sites - features predominantly integrated agriculture-animal management systems. The applications of animal waste are frequent and occur in greater volume around the breeding areas;

M3 - the sample site is placed inside of Marau city and receives effluents from the city of Marau (41,059 inhabitants) (Ramos and Abrantes 2017);

M4 - Marau sub-watershed Outlet site at $14 \mathrm{~km}$ from the city of Marau, integrating urban and rural pollutants; and

G1 - The confluence of two sub-watersheds marks the northernmost point of the Guaporé River. 
Table 1 Catchment area, land use and slope class at the different sampling sites in the Guaporé River

\begin{tabular}{|c|c|c|c|c|c|c|c|c|c|c|}
\hline \multirow{2}{*}{$\begin{array}{l}\text { Sub-watershed } \\
\text { Sample sites }\end{array}$} & & \multicolumn{2}{|c|}{-------------- } & \multirow{2}{*}{$\frac{\text { Capingui River }}{\text { C3 }}$} & \multirow{2}{*}{ C4 } & \multirow{2}{*}{ M1 } & \multirow{2}{*}{$\begin{array}{c}\text { Marau } \\
\text { M2 }\end{array}$} & \multirow{2}{*}{ M3 } & \multirow[b]{2}{*}{ M4 } & \multirow{2}{*}{$\frac{\text { Confluence }}{\mathrm{G} 1}$} \\
\hline & & $\mathrm{C} 1$ & $\mathrm{C} 2$ & & & & & & & \\
\hline Main activities & & Forest & Dam & Agriculture & Agriculture & $\begin{array}{l}\text { Agriculture } \\
+ \text { animal }\end{array}$ & $\begin{array}{l}\text { Agriculture } \\
+ \text { animal }\end{array}$ & Urban & Urban & \\
\hline Catchment area (1 & & 1.3 & 123 & 201 & 267 & 13.4 & 165 & 227 & 256 & 542 \\
\hline \multirow{2}{*}{ Land use (\%) } & Forest & 100 & 28 & 24 & 23 & 22 & 20 & 21 & 22 & 22 \\
\hline & Agriculture & 0 & 64 & 69 & 71 & 72 & 74 & 72 & 72 & 70 \\
\hline \multirow{5}{*}{ Slope Class (\%) } & $0-3 \%$ & 5 & 10 & 9 & 8 & 6 & 7 & 6 & 6 & 7 \\
\hline & $3.1-12 \%$ & 49 & 60 & 59 & 58 & 56 & 60 & 57 & 56 & 57 \\
\hline & $12.1-20 \%$ & 35 & 22 & 23 & 23 & 25 & 23 & 24 & 24 & 24 \\
\hline & $20.1-45 \%$ & 12 & 8 & 9 & 10 & 13 & 9 & 12 & 13 & 11 \\
\hline & $>45 \%$ & 0 & 0 & 0 & 0 & 0 & 0 & 1 & 1 & 1 \\
\hline
\end{tabular}

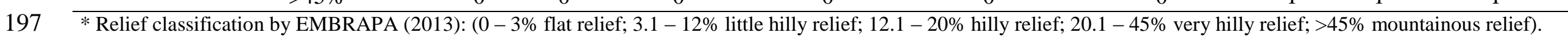


Epilithic biofilms were sampled in the autumn of 2016 (between May 26 and 28) and in the spring of 2016 (between November 12 and 14). The sampling consisted of manual brushing of the material adhered to submerged rock fragments with toothbrushes $(2.54 \times 1$ $\mathrm{cm}^{2}$ ) and $500 \mathrm{~mL}$ of deionized water (Aubertheau et al. 2017; Chonova et al. 2018). The rocks were gently shaken in the river water prior to brushing to remove fine particles of suspended sediment deposited on their surfaces. The number of brushed rocks and the total brushed area $\left(\mathrm{m}^{2}\right)$ was recorded for each sample site. The brushed area for each rock was determined by wrapping each rock in an aluminum foil with a defined grammage, and posterior laboratory weighing of the foil and calculation of the area of the foil (Table 2).

Table 2 Number of brushed rocks and total brushed area at the sampling sites in the Guaporé River

\begin{tabular}{ccccccc}
\hline \multirow{2}{*}{ Sample site } & \multicolumn{2}{c}{ Number of rocks brushed } & & \multicolumn{2}{c}{ Total brushed area $\left(\mathrm{m}^{2}\right)$} \\
\cline { 2 - 3 } \cline { 5 - 6 } \cline { 5 - 6 } C1 & Autumn & Autumn & & Autumn & Autumn \\
\hline C2 & 28 & 33 & & 2.10 & 2.55 \\
C3 & 49 & 32 & & 1.71 & 1.37 \\
C4 & 40 & 45 & & 2.49 & 4.77 \\
M1 & 40 & 5 & & 2.56 & 4.72 \\
M2 & 70 & 96 & & 3.44 & 6.52 \\
M3 & 15 & 100 & & 3.70 & 7.57 \\
M4 & 22 & 33 & & 1.66 & 3.87 \\
G1 & 23 & 33 & & 1.73 & 3.76 \\
\hline
\end{tabular}

The obtained "biofilm suspension" was then poured into glass containers, stored in ice213 cold boxes $\left(4^{\circ} \mathrm{C}\right)$, and transported to the laboratory. Samples were then transferred to 214 individual high-density polyethylene bottles, frozen at $-80{ }^{\circ} \mathrm{C}$ and lyophilized at $-40{ }^{\circ} \mathrm{C}$. 215 After lyophilization, fragments leaves, twig, and invertebrates were manually removed from 216 the samples with a pair of tweezers. With the aid of an agate mortar, samples were ground to 217 obtain a homogenized material.

\section{Pyrolysis coupled to gas chromatography and mass spectroscopy (PY-GC/MS)}

The relative distribution of biopolymers in the biofilms was obtained by PY-GC/MS analysis for only in the biofilm samples sampled in the autumn. The analyses were carried out at the Universite de Poitiers (France). For each sample, about $10 \mathrm{mg}$ of lyophilized, ground 
and dried material was introduced into a small cylindrical quartz tube whose ends were plugged with quartz wool. The tube was placed inside the pyrolyzer Pyroprobe 2000 (CDS Analytical, Inc., Oxford, USA) equipped with a platinum filament. The filament was heated rapidly $\left(20{ }^{\circ} \mathrm{C} \mathrm{ms}^{-1} \mathrm{ramp}\right)$ and held at a high temperature $\left(200-650{ }^{\circ} \mathrm{C}\right)$ for $10 \mathrm{~s}$. Separation and analysis of the products of the thermal decomposition were performed using a gas chromatograph (Hewlett-Packard® HP G1800A operating at EI $=70 \mathrm{eV}$, with scanning from 40-450 a.m.u. (atomic mass units) at 1 scan per s). The system is equipped with BP 20 (SGE Analytical Science) fused silica capillary column $\left(30 \times 0.25 \mathrm{~mm}^{2}\right.$ with $1.0 \mu \mathrm{m}$ film thickness $)$. The temperature of the injector remained at $280{ }^{\circ} \mathrm{C}$ and the temperature used for the detector was $300{ }^{\circ} \mathrm{C}$. The oven was programmed with an initial temperature of $50{ }^{\circ} \mathrm{C}$ and the temperature was raised to $250{ }^{\circ} \mathrm{C}$ with a ramp of $4{ }^{\circ} \mathrm{C} \min ^{-1}$, then held for 2 minutes. Helium was used as carrier gas at a constant flow rate of $1.0 \mathrm{~mL} \mathrm{~min}{ }^{-1}$. Thermal decomposition products (pyrolytic fragments) were identified after examining the NIST (National Institute of Standards and Technology) mass spectral library. The fragments were grouped into seven different families of biopolymers: $\mathrm{N}$-containing compounds, polysaccharides, aromatic compounds, phenolic compounds (polyhydroxy aromatic), fatty acids, lignin, and other compounds (Bruchet et al. 1990), and the relative percentage of each family was calculated.

\section{Nuclear Magnetic Resonance}

The solubility of lyophilized epilithic biofilms samples was tested in several organic solvents: acetone, chloroform, acetonitrile, deuterated water, methanol, and blends of these solvents. We chose methanol $\left(\mathrm{CH}_{3} \mathrm{OH}\right)$ for the extraction of organic compounds from the lyophilized biofilms and deuterated chloroform $\left(\mathrm{CDCl}_{3}\right)$ for the NMR analysis. Three serial extractions were made with $20 \mathrm{~mL}$ each of methanol on $2 \mathrm{~g}$ of lyophilized biofilm, stirring for $24 \mathrm{~h}$ and filtering through qualitative filter paper. The three extractions were combined and evaporated to dryness in a rotary evaporator. The samples were dissolved in deuterated chloroform $\left(\mathrm{CDCl}_{3}\right)$ with $1 \%$ tetramethylsilane (TMS) as an internal reference and transferred to $5 \mathrm{~mm}$ NMR tubes. ${ }^{1} \mathrm{H}$ and ${ }^{13} \mathrm{C}\left\{{ }^{1} \mathrm{H}\right\}$ spectra were acquired at $600.13 \mathrm{MHz}$ and $150.92 \mathrm{MHz}$, respectively, at $298 \mathrm{~K}$. For the ${ }^{13} \mathrm{C}\left\{{ }^{1} \mathrm{H}\right\}$ spectra, the proton couplings were decoupled with power-gated decoupling using a waltz16 pulse sequence. The HSQC ${ }^{1} \mathrm{H}_{-}{ }^{13} \mathrm{C}$ NMR spectra were acquired at $298 \mathrm{~K}$ with the hsqcetgpsi2 pulse program $\left(2 \mathrm{D}{ }^{1} \mathrm{H} / \mathrm{X}\right.$ correlation via double inept transfer using sensitivity improvement, phase sensitive using echo/antiecho-TPPI 
gradient selection with decoupling during acquisition using trim pulses in inept transfer with gradients in back-inept echo-anti echo) using 16 dummy scans and 16 acquired scans and ${ }^{1} \mathrm{~J}_{\mathrm{CH}}$

$259=145 \mathrm{~Hz}$ on a $600 \mathrm{MHz}$ Bruker Avance III HD spectrometer located at the Nucleus for

260 Analysis and Organic Research of the Federal University of the Santa Maria (Brazil).

\section{Spectroscopy in the IR Region with Attenuated Total Reflectance}

Organic constituents and distribution of functional groups were realized with the aid of an Agilent Cary 630 FTIR spectrophotometer from Agilent Technologies was used with a horizontal ATR employing a diamond crystal and zinc selenide ( $\mathrm{ZnSe}$ ) optics and windows. The spectra were obtained in the region of $4000-650 \mathrm{~cm}^{-1}$, with a resolution of $4 \mathrm{~cm}^{-1}$ and 32 scans. Before the readings of each sample, the background IR spectrum was measured using freshly cleaned crystal. Afterward, the direct analysis of the dry samples and lyophilized (in powder form) at room temperature was performed, each sample was spread and compacted on the diamond crystal surface of the ATR and the attenuated total reflectance spectrum was obtained and converted to absorbance by the Kubelka-Munk method. The analyses were carried out at the Laboratory of Inorganic Materials of the Chemistry Department of Federal University of the Santa Maria (Brazil).

275

Statistical procedure

Principal components analysis (PCA) were performed with data obtained from the infrared and pyrolysis analyses of the biofilms. The objective of these analyses was to relate these results with the environmental characteristics of each sample site. Statistical analyses were performed using XLSTAT software in Excel for Windows.

\section{Results}

\section{PY-GC/MS analysis}

Epilithic biofilms were sampled in different environments throughout the Guaporé RW and, as the amount of anthropic pressure differs in each sampling site, variations in the organic constituents of the biofilms are expected, which the PY-CG/MS analysis should 
reveal. The fragments identified in the pyrochromatograms were grouped into seven different families of biopolymers. Their relative distributions varied significantly throughout the subwatersheds. Overall, the biofilms were composed of $22.1-56.8 \%$ of $\mathrm{N}$-containing compounds (C-N); 17.6-41.5\% polysaccharides (PS); 2.3-27.2\% of vegetables (lignin-containing compounds - VEG); 0-8.4\% aromatic compounds (CA); 3.5-21.0\% phenolic compounds (CF); $6.1-14.9 \%$ of fatty acids (lipids - GA), and 0-3.6\% of other organic compounds (Figure 2).

In the pyrochromatograms of the epilithic biofilm samples collected in the Guaporé RW, the main fragments identified were (Figure 3): (A) 3-methylbutanal (PS); (B) Acetonitrile (C$\mathrm{N})$; (C) 1-hydroxy-2-propanone (PS); (D) acetic acid (PS); (E) hexanoic acid (GA); (F) acetamide (C-N); (G) phytol (VEG); (H) 4-methyl phenol (CF); (I) 4-ethyl phenol (CF); (J) 3decen-2-one (others); (K) indole (C-N); (L) methyl indole (C-N); (M) tetradecanoic acid (GA); (N) hexadecanoic acid (AG); (O) 3-methyl-butanenitrile (C-N); (P) pyrrole (C-N); (Q) methyl pyrrole (C-N); (R) decandinitrile (C-N); (S) toluene (CA); (T) phenol (CF); (U) phytol (VEG). The fragments observed confirm the microbial activity in biofilms due to the presence of Ncontaining compounds (Julien et al. 2014), which include proteins, heterocycles, DNA, RNA, among others (fragments B, F, K, L, O, P, Q and R, identified in Figure 3).

In the Capingui River sub-watershed, the fragments of 3-methylbutanonitrile $(\mathrm{O})$ and pyrrole (P) found in the biofilms sampled at the Capingui Dam (C2) site confirming the highest percentage of the $\mathrm{N}$-containing compounds found in the site $(31.1 \%)$, in relation to the biofilms sampled in National Forest of Passo Fundo, FLONA (22.1\%); in Agriculture site, the value increased to $56.8 \%$, with the presence of fragments of methyl pyrrole (Q) and decandinitrile $(\mathrm{R})$.

\section{NMR analyses}

The structural characterization of epilithic biofilms was performed by ${ }^{1} \mathrm{H}$ and ${ }^{13} \mathrm{C} N M R$ spectroscopy. Due to the complexity of the matrix of epilithic biofilms, it was difficult to find a methodology capable of allowing for the visualization of the spectra and their respective peaks of functional groups with minimum interference. The one-dimensional spectra did not allow the unique identification of characteristic peaks of the functional groups. The two dimensional ${ }^{1} \mathrm{H}^{13} \mathrm{C}$ Heteronuclear Singular Quantum Correlation (HSQC) experiment was chosen. The experiment correlates carbon atoms with their bound hydrogen atoms, as seen by 
323 cross peaks between the ${ }^{1} \mathrm{H}$ and ${ }^{13} \mathrm{C}$ spectra (acquired independently) which separates

324 functional groups and spreads the spectra in two dimensions. Proton signals of hydrogen 325 atoms not bound directly to carbon atoms and ${ }^{13} \mathrm{C}$ signals of quaternary carbon atoms are not 326 seen as cross peaks. In the ${ }^{13} \mathrm{C} N \mathrm{NMR}$, the aliphatic hydrocarbons constituting the lipids 327 typically have chemical shifts in the range of 0 to $40 \mathrm{ppm}$; carbon-bonded oxygen bonds (C-O, $328 \mathrm{CH}-\mathrm{O}, \mathrm{CH}_{2}-\mathrm{O}$, and $\left.\mathrm{CH}_{3}-\mathrm{O}\right)$ are in the range 45-60 ppm; carbohydrate alcohols $\left(-\mathrm{CH}_{2} \mathrm{OH}\right), 60$ to $90 \mathrm{ppm}$; and the glycosidic carbon (anomeric carbon that is bound to the alcohol oxygen) of the polysaccharides, 95 and 106 ppm (Jiao et al. 2010; Fialho et al. 2010).

The 2D spectra of ${ }^{1} \mathrm{H}-{ }^{13} \mathrm{C}$ HSQC showed some similarities in the relative abundance and composition of biopolymers present in biofilms (Table 3). The cross peak between 77 ppm (for ${ }^{13} \mathrm{C}$ ) and $7.26 \mathrm{ppm}\left(\right.$ for ${ }^{1} \mathrm{H}$ ) corresponds to the chemical shifts of the residual chloroform $\left(\mathrm{CHCl}_{3}\right)$ in the deuterated solvent $\left(\mathrm{CDCl}_{3}\right)$, and that between $0 \mathrm{ppm}$ for both nuclei corresponds to the internal reference, tetramethylsilane (Figures 4, 5 and 6). In all spectra, cross peaks at the chemical shifts between 0 and $50 \mathrm{ppm}$ (for ${ }^{13} \mathrm{C}$ in $\mathrm{F} 1$ ) and between 0 and 2 ppm (for ${ }^{1} \mathrm{H}$, in $\mathrm{F} 2$ ), which characterize the lipid structures, were observed. They can be identified by cross peaks of the HSQC spectra in the aliphatic region $\left(0-40 \mathrm{ppm}\right.$ for ${ }^{13} \mathrm{C}$ and 0-2 ppm for ${ }^{1} \mathrm{H}$ ) indicating $\mathrm{C}-\mathrm{H}$ bonds of $-\mathrm{CH}_{3},-\mathrm{CH}_{2}$ and $-\mathrm{CH}$ groups (Silverstein et al. 2006).

Table 3 Characteristics of $\mathrm{C}$ and $\mathrm{H}$ displacements detected by NMR - HSQC

\begin{tabular}{cccc}
\hline $\begin{array}{c}\text { C chemical } \\
\text { shift }(\mathrm{ppm})\end{array}$ & $\begin{array}{c}\mathrm{H} \text { chemical shift } \\
(\mathrm{ppm})\end{array}$ & Biofilm constituent & Functional group \\
\hline $0-50$ & 02 & Lipids & Alkanes $(\mathrm{C}-\mathrm{H})$ \\
$50-60$ & $>4$ & Lipids & Ester $(\mathrm{C}-\mathrm{O})$ \\
$50-60$ & $3,2-3,8$ & Polysaccharides & Ethers $(\mathrm{C}-\mathrm{O})$ \\
$60-70$ & $3,5-4$ & Polysaccharides & Alcohol $\left(\mathrm{CH}_{2} \mathrm{OH}\right)$ \\
129 & 5,3 & Lipids, polysaccharides, $\mathrm{N}-$ & Alkenes $(\mathrm{C}=\mathrm{C})$ \\
& & $\begin{array}{c}\text { containing compounds, aro- } \\
\text { matic compounds }\end{array}$ \\
\end{tabular}

The alkyl carbon atoms of the ester groups can be seen in the ${ }^{13} \mathrm{C}$ spectra of all the samples, around $60 \mathrm{ppm}$, at slightly different positions according to the effect of the substituent, but with greater intensity in the Agriculture (C3), Capingui Outlet (C4), Marau integrated agriculture-animal production (M1 and M2) and Marau Outlet (M4) sites. Ethers (C-O-C bond), functional groups that are part of the structure of polysaccharides, also have resonances between 50 and $60 \mathrm{ppm}$. There are structural differences between the samples, 
350 group. By contrast, the epilithic biofilms sampled in C3, C4, M1, and M2 sites showed both ester and ether cross peaks. Esters can be distinguished in the ${ }^{1} \mathrm{H}$ part of the HSQC spectrum, since the hydrogen atoms of the $\alpha$-carbon atom of the acid side of the ether generally exhibit

353 chemical shifts less than $4.0 \mathrm{ppm}$ (3.2 to $3.8 \mathrm{ppm}$ ), whereas the hydrogen atoms of the oxygen 354 atom bonded to the carbon atom of the ether have shifts greater than $4.0 \mathrm{ppm}$ due to the electronegativity of the oxygen atom (Silverstein et al. 2006).

In the chemical shift region of alcohol groups (65-90 ppm) of the carbohydrate groups (of which the polysaccharides are part) significant peaks for all biofilms were observed. In all biofilm samples was visualized the ${ }^{1} \mathrm{H}^{13} \mathrm{C}$ cross peaks around $60-70 \mathrm{ppm}$ and $3.5-4 \mathrm{ppm}$, respectively, indicative of oxygen-connected $-\mathrm{CH}_{2}$ groups, that is, $-\mathrm{CH}_{2} \mathrm{OH}$ (Figures 4,5 and

360 6). Polysaccharide glycosidic carbon atoms were not seen in any of the samples, which may

361 be due to a longer T1 relaxation time. In the biofilms sampled at Capingui Dam (C2),

362 Capingui Outlet (C4), Marau City (M3), and Confluence (G1), C=C cross peaks for alkene groups at shifts of $129 \mathrm{ppm}$ for ${ }^{13} \mathrm{C}$ and $5.3 \mathrm{ppm}$ for ${ }^{1} \mathrm{H}$ were also observed.

\section{IR analysis}

The results of spectroscopy in the IR region obtained for the epilithic biofilms of the Guaporé RW reveal several characteristic IR absorption bands (Figure 7). Twelve main spectral characteristics were observed (Table 4), identified in Figure 7-A, which were grouped according to the main classes of biopolymers. The extracted spectra indicate the presence of polysaccharides, $1300-900 \mathrm{~cm}^{-1}$, as well as $\mathrm{N}$-containing compounds, from $1700-1500 \mathrm{~cm}^{-1}$ (Silverstein et al. 2006; Rossel and Behrens 2010).

Table 4 Characteristics of absorption bands detected by the IR technique

\begin{tabular}{|c|c|c|c|c|}
\hline $\begin{array}{l}\text { Spectral } \\
\text { Characteristic }\end{array}$ & $\begin{array}{l}\text { Wavenumbers } \\
\left(\mathrm{cm}^{-1}\right)\end{array}$ & $\begin{array}{l}\text { Wavenumbers from } \\
\text { literature }\left(\mathrm{cm}^{-1}\right)\end{array}$ & Biofilm constituent & $\begin{array}{l}\text { Functional } \\
\text { group }\end{array}$ \\
\hline 1 & 3694 & $3670-3580^{\mathrm{a}}$ & Phenolic compounds & $\mathrm{O}-\mathrm{H}$ \\
\hline 2 & 3620 & $3670-3580^{\mathrm{a}}$ & Phenolic compounds & $\mathrm{O}-\mathrm{H}$ \\
\hline 3 & 3276 & $3278^{b}$ & Water & $\mathrm{O}-\mathrm{H}$ \\
\hline 4 & 2925 & $2930-2840^{\mathrm{a}}$ & Lipids & $\mathrm{CH}_{2}$ \\
\hline 5 & 1637 & $1640-1550^{\mathrm{a}, \mathrm{b}, \mathrm{c}}$ & $\mathrm{N}$-compounds & $\mathrm{C}=\mathrm{O}$ \\
\hline 6 & 1541 & $1640-1550^{a, b, c}$ & N-compounds & $\mathrm{N}-\mathrm{H}$ \\
\hline 7 & 1030 & $1300-1000^{\mathrm{a}, \mathrm{b}}$ & Polysaccharides & $\mathrm{C}-\mathrm{O}$ \\
\hline 8 & 1005 & $1300-1000^{a, b}$ & Polysaccharides & $\mathrm{C}-\mathrm{O}$ \\
\hline 9 & 910 & $910^{\mathrm{a}}$ & Polysaccharides & $\mathrm{C}-\mathrm{H}$ \\
\hline 10 & 795 & $900-650^{\mathrm{a}, \mathrm{c}}$ & Aromatic compounds & $\mathrm{C}-\mathrm{H}$ \\
\hline
\end{tabular}




\begin{tabular}{lllll}
11 & 780 & $900-650^{\mathrm{a}, \mathrm{c}}$ & Aromatic compounds & $\mathrm{C}-\mathrm{H}$ \\
12 & 746 & $900-650^{\mathrm{a}, \mathrm{c}}$ & Aromatic compounds & $\mathrm{C}-\mathrm{H}$ \\
\hline
\end{tabular}

${ }^{\mathrm{a}}$ Barbosa (2007); ${ }^{\mathrm{b}}$ Viscarra Rossel and Behrens (2010); ${ }^{\mathrm{c}}$ Silverstein et al. (2015).

Polysaccharides are identified by absorption bands between 1030 and $1005 \mathrm{~cm}^{-1}$, which correspond to C-O-C elongation vibrations of ethers, a group of organic fragments which forms part of the polysaccharide structure (Figure 7). Acyclic and cyclic ethers, and related compounds such as acetals and ketals, exhibit typical IR absorption patterns in the region of 1300-900 $\mathrm{cm}^{-1}$ (Barbosa 2007). The absorption band at $1410 \mathrm{~cm}^{-1}$ corresponds to hydroxyl groups $(\mathrm{OH})$ attached to the $-\mathrm{CH}_{2}$ group of polysaccharides (Rossel and Behrens 2010). The significant decrease in the intensity of these bands corresponds to the degradation of carbohydrates (Fialho et al. 2010).

The 1637 and $1541 \mathrm{~cm}^{-1}$ bands are attributed to the primary amides: amide I in proteins and amide II in proteins, respectively (Silverstein et al. 2006; Rossel and Behrens, 2010). Primary amides have a carbonyl group $(\mathrm{C}=\mathrm{O})$ attached to an $\mathrm{NH}_{2}$ group and may also have alkyl or aryl groups attached to the $\mathrm{N}$ atom. In all amides, the IR spectra have an absorption band corresponding to the $\mathrm{C}=\mathrm{O}$ stretching vibration, which is known as the amide band $\mathrm{I}$ (band 5, of Figure 7). In the amide spectra with one or two nitrogen-bonded hydrogen atoms, stretching and angular deformation bands of N-H bonds (amide band II, represented by band 6 of Figure 7) are also observed. The stretching bands of the C-N bond are less important, from the point of view of identification of this class of compounds (Rossel and Behrens, 2010).

The spectra reveal bands typically associated with the aliphatic hydrocarbon portion of fatty acid and lipid molecules (symmetric and asymmetric stretches of $\mathrm{CH}_{3}$ and $\mathrm{CH}_{2}$ in the region of $2980-2800 \mathrm{~cm}^{-1}$ ) at low absorbance intensities. In general, the positions of the absorption bands relative to these stretches varied little, with methyl groups exhibiting the asymmetric stretch absorptions around $2975-2950 \mathrm{~cm}^{-1}$, which could easily be distinguished from the asymmetric stretch of $\mathrm{CH}_{2}$ that appeared around of 2930-2920 $\mathrm{cm}^{-1}$ (Rossel and Behrens 2010). The decrease in the intensity of the bands in this region, as is observed for band 4 at the Capingui Dam (C2) and Agriculture (C3) sites in autumn, indicates the loss of aliphatic structures (Fialho et al. 2010).

Absorption bands 10,11 , and 12 refer to $\mathrm{C}=\mathrm{CH}$ bonds of aromatic compounds since the angular deformations outside the plane of $\mathrm{C}=\mathrm{CH}$ and the angular deformation vibrations outside the ring plane result in absorption bands in the region of approximately $900-650 \mathrm{~cm}^{-1}$. 
406 Absorption bands 1 and 2 are referred to $\mathrm{OH}$ stretching vibrations of phenol groups 407 (Silverstein et al. 2006; Barbosa 2007).

408 Because extracellular polymeric substances are usually mixtures of various 409 biomolecules, some absorption bands may overlap, and even IR characteristic absorption 410 bands may interfere. In this way, some absorption bands could be assigned to different types 411 of compounds. The broad absorption band between 3000 and $3500 \mathrm{~cm}^{-1}$, for example, was 412 attributed to stretching vibrations of both $\mathrm{O}-\mathrm{H}$ of phenolic compounds and $\mathrm{N}-\mathrm{H}$. Absorption 413 bands observed below $1000 \mathrm{~cm}^{-1}\left(795,780,746 \mathrm{~cm}^{-1}\right)$ may belong to phosphoric groups of 414 DNA and RNA or to C-H bonds of aromatic compounds. There is also a possible overlap of 415 the amide band $\mathrm{I}$ at $1650 \mathrm{~cm}^{-1}$ with the absorption bands due to the axial deformation of $\mathrm{C}=\mathrm{C}$ 416 of alkenes and the stretching of $\mathrm{C}=\mathrm{C}$ bonds of aromatic compounds (Silverstein et al. 2006; 417 Barbosa 2007; Sun et al. 2009; Rossel and Behrens 2010; D’Abzac et al. 2010).

\section{Discussion}

Relative distribution of the biopolymers can provide useful information about the origin of the fragments (Julien et al. 2014). Likewise, the high percentage of polysaccharides confirm the production of EPS substances by epilithic biofilms (Fragments A, C and D,

424 Figure 3). Polysaccharides are among the major constituents of extracellular polymeric substances, including the biofilm development stage (Jiao et al. 2010) and are responsible for determining the thickness and "consistency" of the layer of biofilm that develops on the rocks. According to Jiao et al. (2010), thicker and more advanced biofilms present a more diversified microbial community, influencing the production of polysaccharides. In general, bacteria respond to environmental variations or stressing conditions by producing either more or less 430 EPS through their cellular membranes (Jiao et al. 2010; Colica et al. 2014). The composition of EPS also changes to protect the bacterial cells and to favor their acclimatization to their living environment. A high percentage of polysaccharides indicates more production of EPS substances by epilithic biofilms which, in turn, suggests a higher stability and greater protection provided by the environment.

The National Forest of Passo Fundo (FLONA) represents a "quasi-natural environment" because the anthropic action is extremely low due to the establishment of mixed forest almost a century ago. There is no nitrogen input in the system except the natural fixation of $\mathrm{N}_{2}$. The "natural" epilithic biofilms are $22.1 \%$ of biopolymers N-containing and $41.5 \%$ of 
439 polysaccharides (Table 5). The epilithic biofilms monitored in anthropized areas are richer in 440 nitrogen compounds and contain lower levels of polysaccharides than the FLONA samples.

441 The differences in the N-containing/polysaccharide ratios of biofilms are most likely related 442 to direct nitrogen transfers from cultivated soils to watercourses. The agricultural model used 443 in the south of Brazil is based on family agriculture with the integration of grain production 444 (soybean and corn) and animal husbandry (swine, poultry and bovine milk) to industry. In the 445 in anthropized areas, there are three sources of nitrogen to plants: biological fixation of $\mathrm{N}_{2}$ by 446 soybean, animal waste and industrialized fertilizers. In the Guaporé River watershed, 447 representative of South-Brazilian agriculture and also the Mercosur region, there is an excess 448 of nitrogen (Kaiser et al. 2015) and other nutrients (Zafar et al. 2017). Cultivated soils are 449 responsible for more than $90 \%$ of the sediments and nutrients that are transferred to 450 watercourses (Tiecher et al. 2017). The biofilm contents are more related with the anthropic 451 activities along riversides, not having a strong direct relationship with the landscape (Table 5). 452 Except for the FLONA, sampling site with preserved riparian forest, the other sites monitored 453 have similar reliefs and widths of riparian forest and, therefore, are no obstacles to the transfer of pollutants from the crops.

Table 5 Land use (agriculture and animal production), relief and riparian forest affecting the epilithic biofilms composition

\begin{tabular}{|c|c|c|c|c|c|c|c|}
\hline \multirow[t]{2}{*}{ Site } & & \multirow{2}{*}{$\begin{array}{c}\text { Agriculture } \\
\% \\
\end{array}$} & \multirow[t]{2}{*}{$\begin{array}{c}\text { Animal } \\
\text { production }^{*}\end{array}$} & \multirow{2}{*}{$\begin{array}{c}\begin{array}{c}\text { Relief } \\
(3-12 \%)\end{array} \\
\%\end{array}$} & \multirow{2}{*}{$\begin{array}{c}\text { Riparian } \\
\text { Forest width } \\
\mathrm{m}\end{array}$} & \multicolumn{2}{|c|}{$\begin{array}{c}\text { Biofilms composition } \\
(\%)\end{array}$} \\
\hline & & & & & & $\begin{array}{c}\mathrm{N}- \\
\text { containing }\end{array}$ & $\begin{array}{l}\text { Polysac- } \\
\text { charides }\end{array}$ \\
\hline & \multicolumn{7}{|c|}{ Capingui sub-watershed } \\
\hline $\mathrm{C} 1$ & Forest & 0 & - & 49 & $>800$ & 22.1 & 41.5 \\
\hline $\mathrm{C} 2$ & Dam & 64 & + & 60 & $15-60$ & 31.1 & 36.0 \\
\hline $\mathrm{C} 3$ & Agriculture & 69 & +++ & 59 & $<15$ & 56.8 & 24.1 \\
\hline \multirow[t]{2}{*}{$\mathrm{C} 4$} & Outlet & 71 & ++ & 58 & $<15$ & 38.1 & 20.6 \\
\hline & \multicolumn{7}{|c|}{ Marau sub-watershed } \\
\hline M1 & $\begin{array}{l}\text { Integrated } \\
\text { agriculture- } \\
\text { animal }\end{array}$ & 72 & ++++ & 56 & $<15$ & 40.0 & 17.6 \\
\hline M2 & $\begin{array}{l}\text { Integrated } \\
\text { agriculture- } \\
\text { animal }\end{array}$ & 74 & +++++ & 60 & $<15$ & 49.9 & 21.4 \\
\hline M3 & Urban & 72 & $\dagger$ & 57 & $<15$ & 38.7 & 26.5 \\
\hline M4 & Outlet & 72 & +++ & 56 & $<15$ & 30.3 & 25.2 \\
\hline G1 & $\begin{array}{l}\text { Guaporé } \\
\text { River }\end{array}$ & 70 & +++ & 57 & $<15$ & 22.8 & 32.5 \\
\hline
\end{tabular}



in Capingui and Marau sub-watersheds, respectively. In the outlet of the two sub-watersheds, the epilithic biofilms are less rich in nitrogen compounds, expressing a dilution effect since the water flow increases exponentially. This emphasizes that natural resilience occurs in watercourses and the tendency is that these return to their original physicochemical characteristics. In contrast, polysaccharide contents decline linearly from FLONA downstream of the Capingui sub-watershed, reaching only $50 \%$ of the content of "natural" biofilms. Even at the head of the Marau River sub-watershed, the polysaccharide levels are extremely low and are consistent with intense animal production and high cultivated area. In addition, farmers remove the terraces from the no-till system and the width of the riparian forest is insufficient to prevent sediments and animal waste from reaching the small waterways.

In the Marau sub-watershed, the high percentages of phenolic compounds in the biofilms sampled at Marau City (M3) and Marau Outlet (M4) can be explained by the presence of the $\mathrm{T}$ fragment (phenol, Figure 3). For aromatic compounds, the M3 site, characterized by the presence of the city of Marau, presented the second-highest concentration of these compounds (5.4\%). The integrated agriculture-animal production site (M1) presented the highest concentrations (8.4\%) of these compounds. Also, in both sites (M1 and M2), high animal waste production could be responsible for the higher intensity of tetradecanoic acid fragment, highlighting a higher percentage of lipids in these sites $(14.30 \%$ and $14.89 \%$, respectively).

The principal component analysis (PCA) related to the pyrolysis results of the epilithic biofilms sampled in the autumn and their interactions with the soil use and width of riparian forest is represented at Figure 8. The first two components represent $67.12 \%$ of the explanation capacity of the total variance of the set of samples. Through the PCA, it is possible to verify the emergence of relationship among anthropic pressures and biofilms composition. The ligninine derived material (VEG) and PS variables with less anthropized areas $(\mathrm{C} 1, \mathrm{C} 2$ and $\mathrm{G} 1)$ and $\mathrm{C}-\mathrm{N}, \mathrm{CF}$ and $\mathrm{CA}$ associated with the more anthropized ones.

490 These relations are supported by data, particularly showed by first PC, who explains 39,22\%

491 of total variance. The distribution of vectors and sites highlights that soils with agricultural activities increase the presence of nitrogen compounds in biofilms, whilst polysaccharides are related to the forest and less intensive soil uses. 

$(11,5 \%), \mathrm{M} 3(12,0 \%)$ and M4 $(21,0 \%)$ sites appear to be related to urban and in animal activities (Figure 8). Their origin in the waters and, consequently, accumulation in biofilms could be attributed to industrial waste, hydrolysis and photochemical oxidation of organophosphorus agrochemicals and microbial degradation of herbicides (Archela et al. 2003). The monitored site is located immediately downstream of the city of Marau and received the full burden of urban pollution. Aromatic compounds may also have originated from the urban activities occurring in the watershed and can reach water bodies through domestic and industrial effluents, atmospheric origins (through the precipitation of particles and gases from the burning of fossil fuels and wood), and synthesis by organisms. Some organisms such as bacteria, algae, and fungi can produce aromatic compounds naturally through biogenic processes (Catter et al. 2007; Rocha et al. 2007).

Organic compounds that are known to arise from plants are referred to as vegetable chains, which are the result of chlorophyll degradation. The G1 site presented the highest vegetable content, with the presence of the $U$ (phytol) fragment. The presence of a large amounts of microorganisms inside the biofilm matrix leads the hypothesis that the environments less impacted by environmental pressure favor the activity of microorganisms which degrade vegetal pigments constituted by lignin. In this site, due to the great depth of the river at the site, sampling was carried out at the river bank which increases the presence of vegetal fragments (leaves, vegetal residues) and their uptake into the biofilms. The highest concentrations of lipids were found in the confluence (G1), Capingui Dam (C2) and FLONA (C1) biofilms. The microorganisms accumulate a maximum amount of oil to ensure that the growth medium is limiting in the amount of available nitrogen (Ratledge 1991).

Epilithic biofilm structure was similar between the sites, consisting of a mixture of polysaccharides, N-containing compounds, lipids, plant chains, aromatics, and phenolic compounds. This is because the biofilm matrix is naturally (excluding human interference) composed of biomolecules, mainly polysaccharides, proteins, and lipids (Lawrence et al. 2012). It is possible to affirm that the different activities near the sample points will influence the composition of the biofilms developed under the rocks at these sites such as high concentrate nitrate by leaching and runoff after nitrogen fertilizer applications. The presence of nitrate anions may affect the growth of epilithic biofilms, limiting or significantly altering

525 the biomass response to nutrient addition. This process is dependent on the constituents and 526 microorganisms present in the biofilm (e.g., fungi or bacteria) and will influence the tolerance 
527 of epilithic communities (Tank and Dodds 2003). Enrichment of the aquatic environment with 528 nitrogen sources has important implications for nitrogen cycling (Ribot et al. 2015), whereas tolerance of epilithic biofilms suggests an epilithic community more metabolically diverse

530 and with the potential to carry out an active role in the biogeochemical nitrogen cycling (Vila531 Costa et al. 2014).

532 Biofilms from sites with greater development of agriculture will have their composition more marked by higher percentages of $\mathrm{N}$-containing compounds and lower percentages of polysaccharides (Figure 8) because polysaccharide production can be related to the stability and greater protection provided by forest environments or with less agricultural development. Sampling sites with high input of clandestine urban waste have less marked characteristics compared to agricultural areas, with the percentage of $\mathrm{N}$-containing compounds decreasing along the course of the river, as well as the percentage of fatty acids. Sites with less impact will also have a more marked record, mainly by the decrease in the percentage of $\mathrm{N}$ containing compounds at these sites and the considerable increase in the percentages of polysaccharides and vegetable compounds. Considering FLONA as a site of less anthropic interference or "witness", one can verify a tendency of the biofilm to recover its initial characteristics of composition, that is, potential resilience of the epilithic biofilms confronted with the adversities presented in the water course in which they develop.

The presence of lipids shown in the NMR spectra indicates the predominance of longchain hydrocarbons such as tetradecanoic and hexadecanoic acids found in the PY-CG/MS analysis fragments. The most obvious difference between samples is the difference in their relative ethers and esters levels, both were found at points C3, C4, M1 and M2. For chemical shifts in the region of the alcohol groups of the carbohydrate functions, differences in spectral characteristics could be explained by significant differences in the distribution of sugar monomers within polysaccharides (Jiao et al. 2010). Such hydrocarbons may be present in the polysaccharide fragments, in the $\mathrm{N}$-containing and benzene-linked compounds of the aromatic compounds. The differences in polysaccharide peaks between samples are indicative of a difference in carbohydrate composition or the local chemical environment (Reichhardt et al. 2015). As in this work, there was no distinction in the EPS binding to the bacterial cell wall, the large contributions of polysaccharides are consistent with the thick hyphal cell walls of biofilms. NMR techniques also indicated that biofilms exhibit various polysaccharides, proteins, fatty chains, and aromatic structures probably responsible for their binding properties with surfaces (rocks, sediment particles) or other compounds. 

intensity, indicating that the technique was non-discriminant in the composition of epilithic biofilms in qualitative terms (Figure 7). IR analysis shows that polysaccharides absorption bands were similar, both in autumn and spring and between sampled sites. Proteins and lipids absorption bands were larger in the autumn and for virtually all samples.

The ACP was performed from the absorbances and wave numbers obtained in the IR spectra, between the points sampled in autumn and spring (Figure 9). The first two main components represent $82.58 \%$ of the capacity to explain the total variance of the data set. The epilithic biofilms sampled in autumn at C1 (Flona), C2 (Dam) and G1 (Confluence) sites are very similar and have high percentage of polysaccharides and ligninine derived material and low percentages of compounds containing $\mathrm{N}$. The C3 and M2 sites are located near each other which explains the higher concentrations of compounds containing $\mathrm{N}$. The biofilms collected at M1, M3 and M4 sites are in the same quadrant and presented the highest concentrations of phenolic compounds. The epilithic biofilms sampled in spring formed three distinct groups: (a) M4, M1 and C2 sites; (b) M3, M2 and G sites; (c) C1 and C3 sites.

According to D'Abzac et al. (2010), interference between the absorption bands does not allow quantification of the amounts of biochemical compounds present in biofilms, but the IR spectra revealed an overview of the functional groups present. The analysis of PY-GC/MS, on the other hand, had a significant variation in the quantity of each of the individual components of the biofilms.

PY-GC/MS can be used to confirm lipids by the presence of tetradecanoic and hexadecanoic acids in the pyrochromatogram. Lipids can be classified, according to their chemical structure, into hydrolyzable (with ester groups) and non-hydrolyzable (without ester groups). This finding was also reported by many authors (Branda et al. 2005; Jiao et al. 2010; Lin et al. 2014; Zhang et al. 2015), but none of them investigated "in situ" epilithic biofilms directly collected from rocks, especially in a watershed exposed to both to intense agricultural and urban pressures like observed in south Brazil.

Due to their complexity, epilithic biofilms are particularly challenging to analyze chemically, mainly because they represent environmental samples. However, naturally grown epilithic biofilms can be efficiently utilized in reducing some water pollution issues. Epilithic communities are sensitive enough to discriminate the different periods in which nutrients are applied to the environment, mainly through agriculture (land use, seasons and type of crop)

592 (Rheinheimer et al. 2020) and the presence of urban areas (Fernandes et al. 2019), causing, for 
593 example, eutrophication of water bodies near livestock farms. As biofilms show great 594 adaptability to its environment, they can undergo changes due to the capture of the contaminants present in water bodies (Morin et al. 2010; Fechner et al. 2012; Lambert et al.

596 2012). Environmental heterogeneity can be considered an essential factor for the development

597 of spatial resilience in biofilms. In sites with eutrophication, epilithic biofilms can be used as

598 bioindicators of pollution and for water quality assessment. These communities can respond positively to nutrient inputs to some extent and, subsequently, with further enrichment, can lead to changes in the biomass, structure, and functions of the biofilm, all of which can be measured and used in actions to combat and reduce pollution. The efficient use of biofilms at these sites must consider the connections between sustainable farming practices, the nutrient delivery, the biological response, and recovery trajectories in different types of water bodies.

\section{Limitations of the research and future research directions}

The use of epilithic biofilms as a matrix for monitoring the health of water resources is promising, however, the elucidation of the processes of accumulation, transformation and resilience are still insipient in the international literature. The knowledge of the variations in the organic composition of biofilms already is useful as a bioindicator and may aid in understanding their functionality in relation to specific types of pollutants. Brazil has transformed its agriculture into large extensions of genetically modified crops to tolerate 613 pesticides ( 37 million ha of soybean and 14 million ha of corn in 2020). As a result, there is

614 an enormous diversity and quantity of pesticides being transferred to aquatic systems. The 615 detailing of the composition of epilithic biofilms is practically mandatory to the understanding 616 of the dynamics of pesticides in the aquatic environment, such as the accumulation of 617 glyphosate and its metabolite - AMPA (Fernandes et al. 2019). Similarly, Brazil is the largest 618 producer of meat in a confinement system (swine and poultry, specifically) with intensive use 619 of veterinary drugs. The waste is discarded in the soils and indirectly reaches the surface aquatic reservoirs, carrying large quantities of drug residues (Bastos et al. 2018).

The applicability of these analyses in situ is a useful tool for the monitoring of sites exposed with contaminants as, pesticides, drugs, and other organic compounds and the subsequent adsorption of these residues to biofilms. Even with the use of sophisticated techniques and equipment, it is not easy to elucidate in detail the organic complexity of both living biofilm organisms and their exudates. There is a need to integrate studies of the organic 
composition of epilithic biofilms with changes in the microbial community induced by anthropic action (Carles and Artigas, 2020) and their resilience capacity, and even with the appearance of microbial resistance to antibiotics, as demonstrated by Bastos (2017). Another applicability of this analysis protocol is the potential use of biofilms in bioremediation and biotransformation of organic pollutants, as they can tolerate toxic effects of chemicals due to their natural properties and tenacity (Edwards and Kjellerup 2013). Therefore, it is important to carry out the characterization of the entire biofilm by combining the two systems, organisms, and extracellular material.

\section{Conclusions}

636

The PY-GC/MS, IR, and NMR techniques indicated that biofilms exhibit various polysaccharides, proteins, fatty chains, and aromatic structures probably responsible for their binding properties with surfaces (rocks, sediment particles) or other compounds. The use of the chemical composition of epilithic biofilms has proved effective as auxiliary tool for environmental assessment in water courses. Biofilms from more developed agricultural sites will have their composition more marked by higher percentages of $\mathrm{N}$-containing compounds 643 from nitrogen fertilizers applied to the soil and lower percentages of polysaccharides. 644 Biofilms from sites with lower soil use and management intensity, on the other hand, will 645 have higher percentages of lignin-containing compounds and polysaccharides in their 646 composition. Thus, the development of epilithic communities may be influenced by changes 647 that are occurring in the environment and at certain periods of the year, including changes due to greater or lesser intensity of land use or greater or lesser discharge of urban effluents. The study showed the applicability of the methods in in situ sampled epilithic biofilms and confirmed the expected constituents based on controlled systems. Furthermore, observations reinforce the complex biochemical nature of epilithic biofilm communities. Although environmental biofilm systems have been studied for several decades, there are still research gaps to be filled due to the typically heterogeneous composition of this matrix, from a spatial point of view. 


\section{References}

Archela E, Carraro A, Fernandes F, Barros ONF, Archela RS (2003) Considerações sobre a geração de efluentes líquidos em centros urbanos. Geografia 12: 517-525 (in Portuguese).

Aubertheau E, Stalder T, Mondamert L, Ploy MC, Dagot C, Labanowski J (2017) Impact of wastewater treatment plant discharge on the contamination of river biofilms by pharmaceuticals and antibiotic resistance. Sci. Total Environ. 579: 1387-1398.

Barbosa LCA (2007) Espectroscopia no infravermelho: na caracterização de compostos orgânicos. Ed. UFV, Viçosa, Brasil (in Portuguese).

Bastos MC (2017) Study of the environmental contamination of human and veterinary medicines in the south Brazil. Thesis, Universidade Federal de Santa Maria and École Doctorale Gay Lussac da Université de Poitiers.

Bastos MC, Rheinheimer dos Santos D, Monteiro de Castro Lima JA, Le Guet T, Santanna dos Santos MA, Zanella R, Aubertheau E, Mondamert L, Caner L, Labanowski J (2018) Presence of Anthropogenic Markers in Water: A Case Study of the Guaporé River Watershed, Brazil. CLEAN - Soil Air Water 46: 1700019.

Bhuyan MS, Bakar MA, Akhtar A, Hossain MB, Ali MM, Islam MS (2017) Heavy metal contamination in surface water and sediment of the Meghna River, Bangladesh. Environ. Nanotechnol. Monit. Manag. 8: 273-279.

Blanco Y, Rivas LA, González-Toril E, Ruiz-Bermejo M, Moreno-Paz M, Parro V, Palacín A, Aguilera A, Puente-Sánchez F (2019) Environmental parameters, and not phylogeny, determine the composition of extracellular polymeric substances in microbial mats from extreme environments. Sci. Total Environ. 650: 384-393.

Bonnineau C, Artigas J, Chaumet B, Dabrin A, Faburé J, Ferrari BJD, Lebrun JD, Margoum C, Mazzella N, Miège C, Morin S, Uher E, Babut M, Pesce S (2020) Role of Biofilms in Contaminant Bioaccumulation and Trophic Transfer in Aquatic Ecosystems: Current State of Knowledge and Future Challenges. Reviews of Environmental Contamination and Toxicology. 1-39.

Branda SS, Vik $\AA$, Friedman L, Kolter R (2005) Biofilms: the matrix revisited. Trends Microbiol. 13: 20-26.

Bruchet A, Rousseau C, Mallevialle J (1990) Pyrolysis-GC-MS for Investigating HighMolecular-Weight THM Precursors and Other Refractory Organics. J. - Am. Water Works Assoc. 82: 66-74.

Castro Lima JAM, Labanowski J, Bastos MC, et al (2020) "Modern agriculture" transfers many pesticides to watercourses: a case study of a representative rural catchment of southern Brazil. Environ Sci Pollut Res 27: 10581-10598.

Catter KM, Cavalcante RM, Barreto NSE, Saker-Sampaio S, Hofer E (2007) Bactérias isoladas de mangues do rio Cocó e do riacho das Guaribas (CE) e seu potencial na degradação de derivados e constituintes de petróleo. Geochimica Brasiliensis 21: 140-150 (in Portuguese).

Chonova T, Labanowski J, Cournoyer B, Chardon C, Keck F, Laurent É, Mondamert L, Vasselon V, Wiest L, Bouchez A (2018) River biofilm community changes related to pharmaceutical loads emitted by a wastewater treatment plant. Environ. Sci. Pollut. Res. 25: 9254-9264. 
Colica G, Li H, Rossi F, Li D, Liu Y, De Philippis R (2014) Microbial secreted exopolysaccharides affect the hydrological behavior of induced biological soil crusts in desert sandy soils. Soil Biol. Biochem. 68: 62-70.

D'Abzac P, Bordas F, Van Hullebusch E, Lens PNL, Guibaud G (2010) Effects of extraction procedures on metal binding properties of extracellular polymeric substances (EPS) from anaerobic granular sludges. Colloids Surf. B Biointerfaces 80: 161-168.

Didoné EJ, Minella JPG, Merten GH (2015) Quantifying soil erosion and sediment yield in a catchment in southern Brazil and implications for land conservation. J. Soils Sediments 15 2334-2346.

Edwards SJ, Kjellerup BV (2013) Applications of biofilms in bioremediation and biotransformation of persistent organic pollutants, pharmaceuticals/personal care products, and heavy metals. Applied Microbiology and Biotechnology 97: 9909-9921.

EMBRAPA - Empresa Brasileira de Pesquisa Agropecuária. (2013) Sistema Brasileiro de Classificação de Solos. 3.ed. Brasília: Embrapa. 353 p. (in Portuguese).

Fechner LC, Versace F, Gourlay-Francé C, Tusseau-Vuillemin M-H (2012) Adaptation of copper community tolerance levels after biofilm transplantation in an urban river. Aquatic Toxicology 106-107: 32-41.

Fernandes G, Aparicio VC, Bastos MC, De Gerónimo E, Labanowski J, Prestes OD, Zanella R, dos Santos DR (2019) Indiscriminate use of glyphosate impregnates river epilithic biofilms in southern Brazil. Sci. Total Environ. 651: 1377-1387.

Fialho LL, Silva WTL, Milori DMBP, Simões ML, Matin-Neto L (2010) Characterization of organic matter from composting of different residues by physicochemical and spectroscopic methods. Bioresour. Technol. 101: 1927-1934.

Fish KE, Collins R, Green NH, Sharpe RL, Douterelo I, Osborn AM, Boxall JB (2015) Characterization of the physical composition and microbial community structure of biofilms within a model full-scale drinking water distribution system. PloS ONE 10: e0115824.

Flemming HC, Neu TR, Wozniak DJ (2007) The EPS Matrix: The "House of Biofilm Cells." J. Bacteriol. 189: 7945-7947.

Flemming HC, Wingender J (2010) The biofilm matrix. Nat. Rev. Microbiol. 8: 623-633.

Jiao Y, Cody GD, Harding AK, Wilmes P, Schrenk M, Wheeler KE, Banfield JF, Thelen MP (2010) Characterization of Extracellular Polymeric Substances from Acidophilic Microbial Biofilms. Appl. Environ. Microbiol. 76: 2916-2922.

Julien C, Laurent E, Legube B, Thomassin J-H, Mondamert L, Labanowski J (2014) Investigation on the iron-uptake by natural biofilms. Water Res. 50: 212-220.

Kottek M, Rubel F (2010) Observed and projected climate shifts 1901-2100 depicted by world maps of the Köppen-Geiger climate classification. Meteorol. Z. 19: 135-141.

Lambert A-S, Morin S, Artigas J, Volat B, Coquery M, Neyra M, Pesce S (2012) Structural and functional recovery of microbial biofilms after a decrease in copper exposure: Influence of the presence of pristine communities. Aquatic Toxicology 109:118-126.

Lawrence JR, Dynes JJ, Korber DR, Swerhone GDW, Leppard GG, Hitchcock AP (2012) Monitoring the fate of copper nanoparticles in river biofilms using scanning transmission X-ray microscopy (STXM). Chem. Geol. 329: 18-25.

Lin H, Ye C, Lv L, Zheng CR, Zhang S, Zheng L, Zhao Y, Yu X (2014) Characterization of extracellular polymeric substances in the biofilms of typical bacteria by the sulfur K-edge XANES spectroscopy. J. Environ. Sci. 26: 1763-1768.

Matin A, Khan Z, Zaidi SMJ, Boyce MC (2011) Biofouling in reverse osmosis membranes for seawater desalination. Phenomena and prevention. Desalination. 281: 1-16. 
Morin S, Pesce S, Tlili A, Coste M, Montuelle B (2010) Recovery potential of periphytic communities in a river impacted by a vineyard watershed. Ecological Indicators 10: 419426.

Ramos RLO, Abrantes FJ (2017) Marau - IBGE Cidades. INSTITUTO BRASILEIRO DE GEOGRAFIA E ESTATÍSTICA - IBGE (in Portuguese).

Ratledge C (1991) Microorganisms for lipids. Acta Biotechnol. 11: 429-438.

Reichhardt JAG, Ferreira L-M, Joubert KV, Clemons DA, Stevens LC (2015) Analysis of the Aspergillus fumigatus Biofilm Extracellular Matrix by Solid-State Nuclear Magnetic Resonance Spectroscopy Courtney. Eukaryotic Cell 14: 1064-1072.

Rheinheimer DS, de Castro Lima JAM, de Vargas JPR, et al (2020) Pesticide Bioaccumulation in Epilithic Biofilms as Biomarkers of agricultural activities in a representative watershed. Environ Monit Assess. 192:6.

Ribot M, von Schiller D, Sabater F, Martí E (2015) Biofilm growth and nitrogen uptake responses to increases in nitrate and ammonium availability. Aquat. Sci 77: 1-13.

Rocha LL, Aguiar Cordeiro R, Cavalcante RM, Nascimento RF, Martins SCS, Santaella ST, Melo VMM (2007) Isolation and characterization of phenol-degrading yeasts from an oil refinery wastewater in Brazil. Mycopathologia 164: 183-188.

Rossel RAV, Behrens T (2010) Using data mining to model and interpret soil diffuse reflectance spectra. Geoderma 158: 46-54.

Sabater S, Guasch H, Ricart M, Romaní A, Vidal G, Klünder C, Schmitt-Jansen M (2007) Monitoring the effect of chemicals on biological communities. The biofilm as an interface. Anal. Bioanal. Chem. 387: 1425-1434.

Sambalova O, Thorwarth K, Heeb NV, Bleiner D, Zhang Y, Borgschulte A, Kroll A (2018) Carboxylate Functional Groups Mediate Interaction with Silver Nanoparticles in Biofilm Matrix. ACS Omega 3: 724-733.

Schlafer S, Meyer RL (2017) Confocal microscopy imaging of the biofilm matrix. J. Microbiol Methods 138: 50-59.

Schneider SC, Lindstrom EA (2011) The periphyton index of trophic status PIT: a new eutrophication metric based on non-diatomaceous benthic algae in Nordic rivers. Hydrobiologia 665: 143-155.

Silverstein RM, Webster FX, Kiemle DJ (2006) Identificação espectrométrica de compostos orgânicos. LTC, Rio de Janeiro, Brazil (in Potuguese).

Stewart PS, Franklin MJ (2008) Physiological heterogeneity in biofilms. Nat. Rev. Microbiol. 6: 199-210.

Stewart TJ, Traber J, Kroll A, Behra R, Sigg L (2012) Characterization of extracellular polymeric substances (EPS) from periphyton using liquid chromatography-organic carbon detection-organic nitrogen detection (LC-OCD-OND). Environ. Sc. Pollut Res. 20: 3214-3223.

Sun XF, Wang SG, Zhang XM, Paul Chen J, Li XM, Gao BY, Ma Y (2009) Spectroscopic study of $\mathrm{Zn}^{2+}$ and $\mathrm{Co}^{2+}$ binding to extracellular polymeric substances (EPS) from aerobic granules. J. Colloid Interface Sci. 335: 11-17.

Tank J, Dodds WK (2003) Nutrient limitation of epilithic and epixylic biofilms in Ten North American Streams. Freshwater Biology 48 (6).

Tiecher T, Minella JPG, Caner L, Evrard O, Zafar M, Capoane V, Le Gall M, Santos DR (2017) Quantifying land use contributions to suspended sediment in a large cultivated catchment of Southern Brazil (Guaporé River, Rio Grande do Sul). Agric. Ecosyst. Environ. 237: 95-108. 
812 Vila-Costa M, Bartrons M, Catalan J, Casamayor EO (2014) Nitrogen-cycling genes in 813 epilithic biofilms of oligotrophic high-altitude lakes (Central Pyrenees, Spain). Microb. 814 Ecol. 68: 60-69.

815 Wuertz S, Okabe S, Hausner M (2004) Microbial communities and their interactions in 816 biofilm systems: an overview. Water Sci. Technol. 49: 327-336.

817 Zhang Y, Wang F, Zhu X, Zeng J, Zhao Q, Jiang X (2015) Extracellular polymeric substances 818 govern the development of biofilm and mass transfer of polycyclic aromatic 819 hydrocarbons for improved biodegradation. Bioresour. Technol. 193: 274-280. 


\section{Figures}

822

Figure 1 Location of the Guapore river watershed in Brazil and epilithic biofilm sampling

838 Figure 6 Carbon and hydrogen HSQC 2D spectrum for biofilms of the main course of 839 Guaporé watershed sites

Figure 2 Relative distribution of biopolymers in epilithic biofilms collected in autumn in the Guaporé RW

\section{Figure 3 Pyrochromatograms of biofilms samples from Guaporé RW}

Figure 4 Carbon and hydrogen HSQC 2D spectra for biofilms of the Capingui River subwatershed

Figure 5 Carbon and hydrogen HSQC 2D spectra for biofilms of the Marau River subwatershed

Figure 7 IR spectra for epilithic biofilms collected in autumn (A) and spring (B)

Figure 8 Analysis of main components of pyrolysis data from biofilm sampled in autumn at the Guaporé River watershed. Site sampled: C1 to C4 sites in Capingui River watershed; M1 to M4 sites in Marau River watershed; G1 site in confluence (Guaporé River). Organic groups: C-N = N-containing compounds, $\mathrm{PS}=$ polysaccharides, $\mathrm{VEG}=$ lignin-containing compounds, $\mathrm{CA}=$ aromatic compounds, $\mathrm{CF}=$ phenolic compounds, $\mathrm{GA}=$ fatty acids - lipids, Others $=$ other organic compounds.

Figure 9 Analysis of main components of infrared spectra data from biofilm sampled in autumn (blue rhombus) and spring (red rhombus) at the Guaporé River watershed. Site sampled: C1 to C4 sites in Capingui River watershed; M1 to M4 sites in Marau River watershed; G site in confluence (Guaporé River). 